\title{
Museology and Museum-making: Cultural Policies and Cultural Demands
}

La Muséologie et la création de musées : politiques culturelles et demandes culturelles

Olga Zabalueva

\section{OpenEdition}

Journals

Electronic version

URL: http://journals.openedition.org/iss/1183

DOI: 10.4000/iss. 1183

ISSN: 2306-4161

\section{Publisher}

ICOM - International Council of Museums

\section{Printed version}

Date of publication: 15 October 2018

Number of pages: $231-247$

ISBN: 978-92-9012-445-0

ISSN: 2309-1290

\section{Electronic reference}

Olga Zabalueva, "Museology and Museum-making: Cultural Policies and Cultural Demands », ICOFOM Study Series [Online], 46 | 2018, Online since 15 October 2018, connection on 23 October 2019. URL http://journals.openedition.org/iss/1183 ; DOI : 10.4000/iss.1183 


\section{Museology and Museum - making \\ Cultural Policies \\ and Cultural Demands}

\section{Olga Zabalueva}

Lund University, Linköping University, Sweden

\section{A BSTRACT}

What does it take to make a museum? A building designed by world-known 'starchitect'? Public demand? Authentic and exciting collections to present? Committed staff? Generous sponsors? Depending on the context, more questions might arise. However, the question I aim to address is if there is a demand for museological competence in new museum projects, how this competence is being performed and what perspectives there are for further development. The article analyses and compares two museum projects. The first is the Orthodox Church's museum at the New Jerusalem Monastery near Moscow, Russia; the second is a pilot study for the national Museum for Democracy and Migration in Malmö, Sweden.

Key words: Museology, Museum Projects, Church Museums, Migration Museums 


\section{R'́SUMÉ}

\section{La Muséologie et la création de musées : politiques culturelles et demandes culturelles}

Que faut-il pour créer un musée? Un bâtiment conçu par un architecte reconnu ? Une demande populaire ? Des collections authentiques et intéressantes ? Des employés engagés ? Des mécènes généreux ? La liste peut s'allonger en fonction du contexte. Les questions auxquelles je souhaite répondre ici sont plus spécifiques : Existe-t-il un besoin de compétences en muséologie au sein des projets muséaux ? Comment sont utilisées ces compétences et quelles sont leurs perspectives de développements ? Cet article présente deux études de projets de musées : le Musée de l'Eglise Orthodoxe au Monastère de la Nouvelle Jérusalem qui se trouve près de Moscou en Russie et l'étude pilote pour le Musée National de la Démocratie et des Migrations à Malmö en Suède.

Mots clés : Muséologie, Projet Muséal, musée-église, musée des Migrations

\section{*}

Museums as complex institutions of modernity are entangled today in all sorts of power relations. Even though the ICOM museum definition does not say anything about politics, but focuses on collection, preservation, research and communication instead (ICOM, 2017), museums can also be defined as political institutions (Gray, 2015). Tony Bennett (1995) draws on Michel Foucault's theories of power to define the course of the modern museum's inception in the late i8th - igth centuries. Since then, museums developed from the civilising devices set up to fulfil "the task of the cultural governance of the populace" (Bennett, 1995, p. 2I) first into instruments to organize reality (Anderson, 2006) and now they are striving to turn into responsible social actors. The new approaches appeal to museums' social agency and responsibility (Sandell, 2002), promote participatory and inclusive environments (Simon, 2010) and even reduce museums' neutrality in exploring difficult issues (Roque Rodríguez, 2017). This development has taken more than two centuries and is still in progress as even now scholars are working on a new definition of a museum which can include and encompass all the developments (as in the recent ICOFOM anthology edited by François Mairesse, 20I7). Nevertheless, Bennett's analysis of the "exhibitionary complex" or "governmental assemblages" as he addresses museums in his later works (Bennett, 20I5) is still significant for many cultural institutions, not least because of the gap between museum theory and practice which I will identify in the following section. 
Karsten Schubert (2000) argues, that museums have "responded to political and social shifts with seismic precision" (p. II), not least due to the recent developments in the field of museology as a discipline, one might assume. But is it indeed so?

It is a common perception that museums cannot "continue to exist in their present form" in the twenty-first century (Black, 20I2, p. I). What is relevant then for museums that are being planned and designed now? What are the reference points in the world of museum professionals that project managers could use to emphasise the importance for their future museum institution not an archive, an entertainment centre or a spiritual institution? Further on I will discuss the relationship between the existing paradigms in museum-making and the cultural policies that initiate such a process, and illustrate my reflections with two examples, one from Russia and one from Sweden. In both cases the awareness of museology as a discipline was implied from the beginning; however, the outcomes of the projects were as different as the questions posed during their development. The similarity between the two lies nevertheless in the policies and power relations that engendered both projects, commissioned first and foremost by politicians (and by Church authorities, which in contemporary Russia in some cases are almost interchangeable with politicians) of these respective countries.

The aim of my analysis is to answer the question: what does museology have to offer in the turbulent and politically charged field of museum-making?

\section{Something Old, Something New: Exercising Museology in Museum Practices}

In her essay The museology's role in the museum (2017), Kerstin Smeds points out that, before creating a new national museum in Sweden, it is essential to look into the power relations within museums and, at the same time, to define museology's position in the world of cultural institutions. She sees a lack of specific museological competencies in Swedish museums and Swedish cultural policies. This situation is not unique: in Russian 'museumscape', for example, the most valuable skills for the staff are also those of museum's discipline(s), which might be ethnology, archaeology, art history, natural history and others (Gnedovsky, 1997, p. I8; cf. Smeds, 2017, p. 70). However, when it comes to creating a new institution, key decisions, as well as design, are usually made by commissioners or policy makers, and often do not include a museological perspective at all.' As a result, in some cases organisations that are called 'museums' bear no taxonomical attributes of a museum, the words 'to build a museum' mean to, literally, 'construct a building'. At the same time, there is a

\footnotetext{
I. Clive Gray cites Desvallées and Mairesse (20ro, p. 20; cited in Gray, 2015, p. 4) who identify five major functions of museums: preservation, research, communication (which includes education, exhibition and mediation), management and architecture. Gray argues that the fourth function is underrepresented in Museum Studies (at least in the UK) and this might lead to some friction between managerial and collection-based museum professionals.
} 
clear trend in Russian Museum Studies tradition: new competencies, such as project management, are being introduced to museological education (Lebedev \& Shcherbakova, 2009). However, a gap between the theoretical knowledge and its practical implementation is still considerably big, which is common in many countries (for the UK see McCall \& Gray, 20I4).

As "many aspects of contemporary museum policies and politics have been generated out of the discursive co-ordinates which have governed the museum's formation" (Bennett, I995, p. 9), it can be concluded that the emerging demand of museological perspective both in museum projects and museum practices marks an important turning point in the development of museology as a reference system.

Museology itself is a subject to rapid growth. Having started from "anything relating to museums" and the applied discipline which is also called Museum Studies, museology today covers "all the efforts at theorisation and critical thinking about the museal field" (Desvallées \& Mairesse, 20ro, p. 56). A specific development significant for this article is the 'new museology' which started in the r 970 s as the idea that the role of museums in society needed to change (McCall \& Gray, 20I4, p. 20).

The term 'new museology' was introduced in the Anglo-American sector of museum studies in 1989 by Peter Vergo in the book of the same title (Vergo, I989). The book focused on the context of museums, presenting them not as detached, objective institutions but as complex structures with relations to the social, political and economic environment. A decade earlier, the same term was used by André Desvallées (Desvallées \& Mairesse, 20I0, p. 55) in his concept of la nouvelle muséologie that emphasises the social role of the museums and its interdisciplinary character. These concepts influenced the gradual changes in the role of Western museums since the ig6os-I970s.

The new museology principles are being perpetually used in diverse national traditions since then (e.g. Stam, I993; Sandell, 2002; Black, 20I2; the ICOM's International movement for a New Museology which was founded in I985), even if they are called by different names. Furthermore, as Deirdre Stam (1993) notices, "few New Museologists seem particularly conscious of the history of this discipline" (p. 56). Furthermore, even though the literature that can be considered as the part of the new museology's discourse is burgeoning, ${ }^{2}$ there

\footnotetext{
2. I am considering most of the recent changes in museological perspective that are mentioned in literature, as inherent to the 'new museology', even if the authors did not mean to draw on this movement. Sabine Coelsch-Foisner suggests for such changes a concept of the 'museal turn' which, according to her, includes "the creation of alternative or diverse narratives, a foregrounding of the dignity of people rather than their victimisation in history, the changing relation between the museum and the visitor, the levelling of social differences for the purpose of visitor identification, [...] a new democracy calling for community involvement and visitor interaction, as well as creative engagements with the museum" (Coelsch-Foisner, 20I2, p. 15). The shift, therefore, is claimed to be made from the authoritative homogenous narrative to participative representation, from collec-
} 
has been no definite shift from the theoretical stance to the practical field of museum work. Stam points out that the new museology "has not so far explained exactly how [its] theoretical framework should be translated into practice" (I993, p. 55); 20 years later in an extensive study of British cultural institutions Clive Gray and Vikki McCall state that "the 'new museology' is less useful for praxis - museums have been left to find their own routes to link ideas around the 'new museology' to what they are actually doing" (20I4, p. 2I). This, however, concerns already established institutions whereas this article is focusing on the museum projects.

The notion of 'museum project' can be perceived as a very broad definition of museum-based activity, from the exhibition design to museum education or social media management. In this article, I use it mainly for the whole institution designed from scratch, as it will be further shown in two museum examples. Museum projects always have a sociocultural meaning as sociocultural projects aim to make a difference in society through culture (Lebedev \& Shcherbakova, 2009). Furthermore, as Richard Sandell (2002) argues, instead of focusing on complex outcomes that are difficult to measure, such as creating national identity (cf. Aronsson \& Elgenius, 2015), museums are able to

impact positively on the lives of disadvantaged or marginalised individuals, act as a catalyst for social regeneration and as a vehicle for empowerment with specific communities and also contribute towards the creation of more equitable societies (Sandell, 2002, p. 4).

Such an ambition demands a constantly developing framework that will help to recognise both museums' social agency and responsibility and to implement the theoretical findings of new museology in practice. As museums can be seen as turning gradually into 'hybrid fora' of modernity (Sadighiyan, 2017), museology as a discipline can also be perceived as such a forum or an institutional network, that will provide its knowledge to 'profanes', first and foremost to policy makers, and inform the actors involved in museum-making processes. The one 'new museological' feature that is most relevant for the two museum projects in this article is the ability of museums to serve as a platform for public dialogue; the cases were chosen to illustrate how this ability can be performed at the conceptual stage and the intersection of the political and museological power relations at this point.

There is another angle in the relationship between the museum and the visitor that should be mentioned. Bennett (1995) notes that there are 'cultural barriers to participation'. As he states, the "sections of the population which make little use of museums clearly feel that the museum constitutes a cultural space that is not meant for them" (Bennett, I995, p. I04, emphasis added by me). Other researchers, however, position museums in consumer cultures as an intersection of economy and culture, and use a wide variety of notions, from 'edutainment' 
to 'McDonaldisation' and 'Disneyfication' (Schwend, 2012). These phenomena provide grounds to ponder the inevitable changes in the relations between museums' supply and public cultural demands. For instance, the recent studies on the interest in museums among the general public in Russia (Chuvilova \& Shelegina, 2015) show that "the demand for museum services is directly related to the general educational and cultural level of a society and, in particular, to the culture of leisure" (p. 307).

Having in mind the appeal for 'transforming museums in the 2Ist century' (Black, 20I2), we could pose a somewhat exaggerated question: what if it is more rational to create a brand-new museum, that will answer any relevant demand both from the audience and stakeholders than to remake an old one? Schubert (2000) states that it's easier to come up with a brand-new project than to reform an established institution (p. 9o). The museum as a 'cultural technology' (Bennett, 1995) has a specific catch in its mechanics that allows it to endure external changes, adjust to them and keep its internal structure. However, even recently created museums cannot avoid the publics' preconception of the museum as an institution - as well as museums' preconception of their audiences. For example, in a study on participatory techniques in museum narratives, the visitors longed "for an authoritative, expert voice, and... [did not] perceive their own contributions as necessarily relevant or interesting" (Becker-Proriol \& Chanay, 20I2, p. 327). Anna Leshchenko in her contribution at the 39th ICOFOM annual symposium (2016) suggests the term 'conscious museum' which, among other things, accepts "that there are 'inactive' visitors who prefer passive slow contemplation" (p. 4). So, alongside the demand for a new kind of cultural space, there is another demand which prompts museums to organise this space in a mindful, informed way ("to be all things to all people" as McCall \& Gray describe these multiple demands; 20I4, pp. 27-28). Museums are still perceived as instruments of public instruction and are supposed to form a context for "governmental programmes aimed at reshaping general norms of social behaviour" (Bennett, I995, p. 6). However, these norms have changed. Where in the r 9 th century a Foucauldian disciplinary institution depicted by Bennett has emerged, there is now a place for multifaceted representation, as "norms have become more liberal and more pluralist, with the slow take-over by consumerism" (Schwend, 20I2, p. 30).

The two case studies of this paper represent two different approaches to the implementation of the museological perspective in developing new museum projects. Simultaneously, both projects answer the current political demands of the respective country, be it the revision of the Orthodox heritage and the formation of the historical narrative of pre-Petrine Russia or the multiculturalism and democratic discourse in the context of so-called 'migration crisis' in Sweden. 


\section{A Progressive Museum-making, or There and Back Again}

The Russian case includes a pre-existing museum that illustrates different phases of museum-building, from gathering personal memorabilia and historical curiosities in the igth century to the universalist regional collections of a new secular establishment after i917. This existing museum makes a discussion about creating a new museum rather complex. To begin, I will briefly address the place and its history.

The Resurrection New Jerusalem Monastery is an Orthodox male cloister on the outskirts of Moscow founded in 1656 as the residence for Patriarch Built during the Patriarch Nikon's Orthodox church reformation. The monastery was conceived as an earthly reflection of the Heavenly Jerusalem, where all the buildings and topographical elements represented corresponding parts of the Holy Land. The new monastery was commissioned jointly by the Patriarch and the Tsar, and its specific feature was the participation of Western architects and craftsmen in the construction, as well as the recruiting of Orthodox monks from all over the Muscovy state and beyond. During the I7th to I9th centuries, the monastery was a centre of arts, crafts, knowledge and spiritual activity; the second half of the igth century was marked by the interest in the monastic and cultural heritage of the area. In the I87os the Museum of Patriarch Nikon was founded by the monastery's rector.

The Soviet period enforced secularisation: the monastery was closed in 1918 and in 1920 the Museum of Arts and History was founded on its premises. The museum soon became a centre for regional history. A big part of the museum's collections was formed from the church treasuries and expropriated liturgical objects. In 194I the monastery was blown up by the German army, the bell tower and part of the cathedral were destroyed, along with the museum and some of its collections. Restoration work started in the 1950s and took more than a half of century to complete. The state museum was reopened in the remaining part of the monastery in 1956 and played an active role in preservation and restoration processes. The collections grew rapidly and presently include not only church history related objects, but also paintings, documents, photographs, archaeological and ethnographic materials.

In 1994 the monastery was re-established as an institution of the Russian Orthodox Church, and in 2012-2014 the state museum 'New Jerusalem' was relocated to the newly constructed building outside the monastery complex and renamed a regional museum and exhibition centre. At the same time, in the zoros a new actor in restoration and re-establishing of the monastery has emerged, the Charitable Foundation, with honorary Board members such as the then-president Dmitry Medvedev or the Patriarch of Moscow and All Russia Kirill, as well as senior officials from the state-run corporations. The Foundation and the Russian Orthodox Church suggested establishing a new, church-driven museum in the monastery, which would allow the presentation of outstanding architectural monuments and the sacral topography of the monastery both to 
Orthodox pilgrims and profane visitors. It was also believed that the narrative of the Palestine-near-Moscow, as the monastery is often called, would not be relevant and authentic if located outside the cloister walls (in the new state museum's building). 3 The future church museum was therefore conceived as a connection, a missing link between the monastic and church routines and a regional cultural centre (the relocated state museum).

The new museum project, named Centre for Cultural Studies of the Muscovy State and the Museum of Patriarch Nikon (Baranova et al., 20I4), ${ }^{4}$ was presented to the Advisory Board of the Foundation in autumn 20I4. The project development involved both archaeological and historical expertise, as in the 2010 s the extensive archaeological investigations were conducted alongside the reconstruction process. A long-established view of the museum as a temple (Cameron, I97I) was also considered during the project design phase. However, the creation of the actual museum was postponed.

The Museum of Patriarch Nikon was envisaged as a core institution for a larger research centre, the mission of which would be to form the national and religious identity of the Russian people as Christian Europeans through representing the New Jerusalem cultural heritage from the 'golden age of the Muscovy state' (Baranova et al. 20I4, p. 3r). Here we can see a controversial point, as the interest in the pre-Petrine Russian history traditionally comes together with the national-building processes, for example in the igth century when the monuments of the first tsars from the Romanov dynasty were memorialised, as I discuss elsewhere (Zabalueva, 2017). A historical discourse that emphasises the importance of the Pre-Petrine period is usually applied when the argument for advantages of 'non-Western' development of Russia is taking place. According to the popular belief, only Peter the Great made a decisive choice of turning Russia into a Europe-oriented empire. Russian archaeologist Leonid Beliaev (2013), though, addresses the New Jerusalem as 'the religious version of proto-St. Petersburg' of its time and argues that Patriarch Nikon has implemented one of the early modernisation programmes in Muscovy Russia, fifty years before Peter the Great and his reforms.

\footnotetext{
3. The problem of reassessing Orthodox heritage is a grave and significant issue for Russian cultural institutions. In 2010 a Federal Law was signed by the Russian president that among other things prescribed restitution of the state property to the religious organisations which owned this property before 1917 (The Russian Government, 20I0). This law has no power over state museums' collections; however, in some cases of restitution, a clash between religious and cultural organisations has occurred. During the Soviet period, a lot of churches were perceived as historical and architectural monuments - sometimes musealisation of a building saved it from demolition. In the r99os the Orthodox heritage became the focus of interests of diverse groups and communities, causing a tension in various levels of society. Even though this topic lies beyond the scope of the current article, it is still necessary to mention as it deeply influences heritage-related processes in this case setting. 4. I was a part of the project team, and I want to thank the project curator, Dr Svetlana Baranova, and the leading expert, associate member of the Russian Academy of Sciences, Dr Leonid Belyaev, for the permission to use the unpublished concept for this paper.
} 
During the establishment of the monastery the most important role was played by the personality of the commissioner - the Patriarch himself. It was Nikon who planned and performed the important turn in the history of the Russian Orthodox Church (the schism) as well as transformed a piece of countryside near Moscow into his own fragment of the Holy Land. His project was left unfinished for many reasons, and the modernisation of the ancient Russian state was postponed for a few decades. Ironically, the commissioners' role in the 20I4 museum project was as vital for the project and its ambitious scope. The planned research centre intended to gather archaeologists, historians and other scientists focusing on the late Muscovy State's history and become a hub for national and international conferences. 5 One of the aims was to attract public attention to the underestimated and controversial period of Russian history and inform the audience about issues that, to a large extent, had an impact on the nation-building of the modern Russian state. Contributors to the project had their own speciality interests in focus, and the idea of the museum as a universalist temple of science/knowledge/spiritual enlightenment was highly appreciated by commissioners, both from the side of the Russian Orthodox Church and of the State authorities.

It is hard to say why the proposed new museum has not become a reality. The restoration works were almost finished, and now the monastery's architectural heritage is presented to visitors in all its glory. Thus, a complex institution with the traditional mission of civilising the populace was substituted by establishing a tourist attraction. The eventual failure of the project might depend on the lack of dialogue with the local and professional communities as well as on the global range of the suggested institution. The cultural demand for this specific museum was not clearly articulated, whereas the more general idea of the musealisation has been traditionally performed by the state museum. The 'cultural space' of the prospective museum has not been conceived for any specific group, and the unique environment of the monastery, that was indicated as one of the important resources for the project, has been set aside. The studies of the New Jerusalem heritage, however, continue both in form of archaeological investigations and academic conferences, and it is still possible that further findings will help to reconsider the 20I4 project and put it into action.

\footnotetext{
5. One of the technological innovations introduced in New Jerusalem in the $17^{\text {th }}$ century was a vast usage of decorative ceramic tiles in architecture. Being perceived in literature as a 'laboratory' for ceramic arts and crafts, the monastery became a point of interest for all involved in this kind of research. In 2014 and 2015 two national conferences on Ceramic Arts and Crafts were held in the monastery's premises with the help of the project team, and one of the focuses for the Museum of Patriarch Nikon would have been the art of ceramic tiles of the late Russian Middle Ages (cf. Baranova, 2009).
} 


\section{A Commissioned Democracy or Flexible Networks on the Move}

At first glance the Swedish case may seem different. There wasn't any previous museum dedicated to both migration and democracy issues, not to mention locating a national museum outside of Stockholm (Swedish national museums are located mainly in Stockholm except for the National Museums of World Culture which have headquarters in Gothenburg). The decision to establish such a museum was in many aspects a political one.

In 2015-20I6 the European Union has faced a 'migration crisis', that, according to some of the analysts, threatened core European rights and values (Borg-Barthet \& Lyons, 2016). Tightened borders, changing rules and the rise of populistic rhetoric both inside and outside the EU have once again pinned the importance of the migration narratives communicated by the cultural institutions and museums in particular (Gourievidis, 20I4; Levitt, 20I5; Johansson, 20I5; Levin, 2017). In 2015, the Network of European Museum Organisations published the recommendations for museum work in the field (NEMO, 2015).

For Sweden, the importance of such communication is obvious, as the country received more asylum seekers in 2015 than ever before (Migrationsverket, 2016). A lot of issues came up in the public debate, and most Swedish museums are, in one way or another, working with the questions of migration (Kulturförvaltningen, 20I7, p. 4I). The southern Swedish city of Malmö, which connects Sweden to the continent through the Öresund bridge, became one of the thot spots' for the migration discourse and a gateway for many refugees. In May 2016, the international conference Museums in Times of Migration and Mobility: Processes of Representation, Collaboration, Inclusion and Social Change was held at Malmö University. Here, among other things, the pilot study done by the Department of Culture of the city of Malmö was presented.

The study, initiated by the city council and supported by the Swedish government, aimed to investigate the preconditions required to set up a National Museum for Democracy and Migration in Malmö. The commissioners, therefore, were Malmö City's politicians and one of the project's aims was to contribute to sustainable city development. Located on the Swedish-Danish border, being historically a transit city and a door for the better future for hundreds of thousands of Swedes who left their country at the turn of the 2oth century, fleeing famine and unemployment; a safe haven for refugees since the World War II, Malmö is conceived as an international meeting place. In the Malmö Institute for Studies of Migration, Diversity and Welfare of Malmö University, the migration studies are one of the research focuses. Other actors contributing to the pilot study for a new museum were the Swedish History Museum, the Swedish National Museums of World Culture and the Swedish Exhibition Agency; all three were assigned by the Swedish government to provide assistance to the Malmö city's Department of Culture. The study included field research on similar institutions and preservation/exhibition techniques (Museum of 
Immigration and Diversity, London; Open Society Archives, Budapest; Le Musée des Civilisations de l'Europe et de la Méditerranée, Marseille; People's Museum, Manchester etc.) and academic peers were also invited to collaborate on the project (Kulturförvaltningen, 2017).

The study was conducted in the form of a public dialogue. The meetings with civil society actors and museum professionals were arranged all over the country to explore the issues of democracy and migration. National minorities representatives, as well as Malmö citizens, also took part in the discussion. The meetings' participants were encouraged to contemplate how the five basic notions for the pilot study (national, democracy, migration, museum and Malmö) could be represented in one institution, what kind of institution it might be, how the issues of democracy and migration would be addressed and if the city of Malmö is the right place to establish such a museum (Kulturförvaltningen, 2017, p. 27). The pilot study was conducted during 2016-2017, and a final report was published in Spring 2017 alongside an anthology of researchers' essays and the data from the meetings, workshops and study visits. The project has been transformed during the study, and the final report is called Museum of Movements (Kulturförvaltningen, 20I7).

The theme of migration is sometimes overexploited in modern museums (Lanz, 2015). Joachim Baur argues that migration museums are contributing to the revision of the nation by putting the image of the 'other' on display (cited in Sutherland, 20I4; see also Nikolić, 20I5 for the similar critique of imagined migration museum in Malmö). In Sweden, a migrant figure in popular belief is presented by a foreigner ("invandrare", or an "immigrant" in Swedish) who recently came to Sweden, in most cases as a refugee. The Museum of Movements project, however, focuses on migration as a movement, and also on popular movements and activism as a core concept for democracy. This focus might serve as a way out of the framing and exhibiting the 'other'. The notion of 'movements' does not necessarily specify if the museum's narrative draws public attention to immigration, emigration, or the internal movements of the populace. Popular movements and public engagement as the future museum's themes also imply, if unconsciously, the acknowledgement of the new museology's principles, and not only let the prospective visitors' voices be heard but also include these visitors in the museum-making process.

The political importance of the project was debated in Swedish media and brought out some points in the public conception of what museums are. As an (extreme) example, a concern was expressed by the right-wing political Swedish Democrats party that such a museum will become a political instrument for multiculturalism and will promote further high immigration rates to Sweden (Sverigedemokraterna, 20I7). From the other side of the political spectrum, the socialist writer Staffan Jacobson states in his blog that "it's not the left but the right that belong to a museum" (Jacobson, 20I7). Being immersed into the political power relations from the very beginning, the Museum of Movements has already achieved agency and became, even if virtually, a place 
for public dialogue ${ }^{6}$. Even though the museum is envisioned through and due to a certain political discourse and its conception carries the attributes of governmental regulation (it is supposed to create a broader understanding of the phenomenon of migration and make it more intelligible at the local level, see Kulturförvaltningen, 2017, p. 5I), the very focus on democracy allows for engaging the audience and activates bottom-up initiatives. Another vantage point to be highlighted is an inclination towards the agile organisational structure for the future museum. As the museum has neither a specific building at its disposal nor the full-time staff or established collections, it acts as a flexible system of projects that complement one another and create the base for the future organisation. One can even say that the Museum is a Movement itself.

\section{Conclusion}

In both cases presented, the museum projects were directly affected by the current politics in their respective region. The influence of museological discourse, if intangible and somewhat tentative, can also be traced: for example, the conception of New Jerusalem's museum was reassessing the notion of 'museum as a temple' and turning it into 'the temple as a museum'; and for the Museum of Movements a demand for specific museological competence is stated in the pilot study's report (which refers to Kerstin Smeds, see Kulturförvaltningen, 2017, p. 67), not to mention the contemplation of the future museum's social agency and ability to 'make a difference' (Kulturförvaltningen, 2017, p. 7). Both were conceived as somewhat ideal museums for their respective contexts, be it a thriving I7th-century heritage or the multiculturalism and inclusive policies of modern "humanitarian superpower" as Sweden positions itself (cf. Aggestam \& Bergman-Rosamond, 20I6, p. 326). The initial question for both projects, however, is disparate: in the Russian case, it is 'What kind of museum should be established?' and the Swedish one is 'Why do we need to establish a museum in the first place?'. Each of these questions requires different methods and addresses different aspects of museological discourse. Both projects were made after the commissioners' policies. The museum in New Jerusalem should have presented a vision of the Orthodox heritage and act as Kulturträger, a 'bearer of culture' in connection to the secularised state museum's collections. However, the extensive scope of the project and its universalist character hindered its implementation by the same commissioners who have voiced their demand for such an institution. Instead, the Museum of Movements enacted a public dialogue, based on the current policy of the Swedish Ministry of culture, even though the application of (new) museological methods was not fully recognised in the process.

\footnotetext{
6. It worth to mention that the idea of establishing the state-funded museum of immigration in Malmö was brought up already in 2006, but "the proposal did not spark any public debate and an immigration museum never materialized" (Johansson, 2014, p. I24).
} 
Whenever the museum's social agency is discussed in the literature, the visitor/ consumer based approach often comes into focus. Jerome De Groot in his piece on Consuming History observes that "those who live in a land are stakeholders in its history, owners, clients, customers; they have rights and the ability to demand" (as cited in Schwend, 20I2, p. 26). Furthermore, a 'conscious' museum (Leshchenko, 2016) should be aware of the national and international practices in the field of museology and Museum Studies as well as their relevance to the specific situation - and through that be granted the ability to make an informed choice.

My implication is that the international museum community could be, in its turn, a 'stakeholder, owner, client and a customer' for museology just as visitors are for museums. The literature often stresses the politics and power relations in museums, however, museums are turning more and more into a process rather than being an institution (Smeds, 2017, p. 7I), a fluid network of connections, and a technology (still aimed for differentiation and homogenisation at the same time, see Bennett, 1995, p. 28). An interdisciplinary research grounded in the museological perspective can contribute to the future museum projects by informing both museum professionals and policy-makers, designating important points in the process and mapping the cultural demand. This approach allows for applying a broad variety of methods in each individual case, for example, to explore further the engagement of civil society organisations in the museum-building process; or to perceive a church museum as a hybrid forum to discuss the controversial prospects of the Orthodox church and national heritage in Russia.

Museology, therefore, can have the same social agency and responsibility, and be as 'conscious' as a museum in general. In such a manner, it might perform as a key actor in the process of museum-making.

\section{References}

Aggestam, K. \& Bergman-Rosamond, A. (2016). Swedish Feminist Foreign Policy in the Making: Ethics, Politics, and Gender. Ethics \& International Affairs, 30(3), 323-334.

Anderson, B. 2006. Imagined Communities: Reflections on the Origin and Spread of Nationalism. Rev. ed. London: Verso.

Aronsson, P., \& Elgenius, G. (Eds.) (2015). National Museums and Nation-Building in Europe 1750-2010. Mobilization and legitimacy, continuity and change. London and New York: Routledge.

Baranova, S. (2009). Sozdaem muzej izrazca [Creating a museum of ceramic tiles]. Muzej, 3, 36-40. 
Baranova, S., Belyaev, L., \& Zabalueva, O. (20I4). Muzej patriarha Nikona i Centr po izucheniju duhovnoj kul'tury Moskovskogo gosudarstva XVII - pervoj poloviny XVIII vv. Koncepcija sozdanija i razvitija [Museum of Patriarch Nikon and Centre for Cultural Studies of the Muscovy State in I7th - first half of the i8th centuries. Establishing and development concept]. Fond po vosstanovleniju Voskresenskogo Novo-Ierusalimskogo stavropigial'nogo muzhskogo monastyrja. [Unpublished manuscript].

Becker-Proriol, J., \& Chanay, R. (20I2). Have Museums Lost Their Voice? In S. Coelsch-Foisner, \& D. Brown (Eds.), The Museal Turn (pp. 317-331). Heidelberg, Germany: Universitätsverlag Winter.

Beliaev, L. (2013). Voskresenskij Novo-Ierusalimskij Monastyr' kak pamjatnik arheologii nachala novogo vremeni [Resurrection New Jerusalem Monastery as the archaeological monument of the early modernity]. Rossijskaja arheologija, I, 30-4I.

Bennett, T. (1995). The Birth of the Museum: History, Theory, Politics. London \& New York: Routledge.

Bennett, T. (2015). Thinking (with) Museums: From Exhibitionary Complex to Governmental Assemblage. In A. Witcomb, \& K. Message (Eds.), The International Handbooks of Museum Studies: Museum Theory (pp. 3-20). Chichester, West Sussex: Wiley/Blackwell.

Black, G. (20I2). Transforming Museums in the Twenty-first Century. London \& New York: Routledge.

Borg-Barthet, J., \& Lyons, C. (2016). The European Union Migration Crisis. Edinburgh Law Review, 20(2), 230-235.

Cameron, D. F. (r97I). The Museum, a Temple or the Forum. Curator: The Museum Journal, I4(I), II-I4.

Chuvilova, I., \& Shelegina, O. (2015). The Museum's Mission in the Modern Society and Problems of Museum Communication (With a Focus on Russia). ICOFOM Study Series, 45b, 303-313.

Coelsch-Foisner, S. (2012). The Museal Turn: Introduction to a New Concept in Cultural Studies. In S. Coelsch-Foisner, \& D. Brown (Eds.), The Museal Turn (pp. II-I6). Heidelberg, Germany: Universitätsverlag Winter.

Desvallées, A., \& Mairesse, F. (Eds.) (2010). Key Concepts of Museology, International Council of Museums. Paris: Armand Colin.

Gnedovsky, M. (I997). Modernizacija muzejnogo dela v Rossii [Modernization of Russian museums]. In N. Nikishin (Ed.), Muzej i demokratija (pp. 7-20). Moscow: Rossijskij institut kul'turologii.

Gourievidis, L. (Ed.). (20I4). Museums and Migration: History, Memory and Politics. London and New York: Routledge. 
Gray, C. (2015). The Politics of Museums. London: Palgrave Macmillan.

ICOM (2007). Museum Definition. [Online]. Retrieved from http://icom. museum/the-vision/museum-definition/

Jacobson, S. (2017). Krönika 28-29/3 2017. Högern passar bäst på muséet! [Blog post]. Retrieved from https://anarchyisorder.wordpress.com/2017/03/27/ kronika-28-293-20I7-hogern-passar-bast-pa-museet/

Johansson, C. (20I4). The Museum in a Multicultural Setting: The case of Malmö Museums. In L. Gouriévidis (Ed.), Museums and Migration: History, Memory and Politics (pp. I22-137). London \& New York: Routledge.

Johansson, C. (2015). Museums, migration and cultural diversity: Swedish museums in tune with the times. Innsbruck, Austria: Studienverlag.

Kulturförvaltningen, Malmö stad. (2017). Rörelsernas museum: Förstudie om ett nationellt demokrati- och migrationsmuseum i Malmö [Museum of Movements: Pilot study on a national Museum for Democracy and Migration in Malmö]. Malmö, Sweden.

Lanz, F. (2015). Staging Migration (in) Museums. A Reflection on Exhibition Design Practices for the Representation of Migration in European Contemporary Museums. Museum \& Society, I4 (I), I78-192.

Lebedev, A., \& Shcherbakova, A. (Eds.). (20o9). Muzejnoe proektirovanie [Designing museums]. Moscow: Laboratorija muzejnogo proektirovanija, Rossijskij institut kul'turologii.

Leshchenko, A. (2016). Conscious museum: Presentation text for "Predatory museology" session on 6 July 2016, at the 39th ICOFOM annual symposium "The Predatory Museum" in Milan. Retrieved from: https://www.academia. edu/34330774/Conscious_museum

Levin, A. K. (Ed.). (2017). Global Mobilities: Refugees, exiles, and immigrants in museums and archives. London \& New York: Routledge.

Levitt, P. (2015). Artifacts and allegiances: how museums put the nation and the world on display. Oakland, California: University of California Press.

Mairesse, F. (Ed.). (20I7). Définir le musée du XXIe siécle. Matériaux pour une discussion. Paris: ICOFOM.

McCall, V., \& Gray, C. (2014). Museums and the 'new museology': theory, practice and organisational change. Museum Management and Curatorship, 29(I), I9-35.

Migrationsverket: Swedish Migration Agency. (2016). Nearly 163,ooo people sought asylum in Sweden in 2015. Retrieved from: https://www.migrationsverket. se/English/About-the-Migration-Agency/News-archive/News-archive2016/2016-oI-I2-Nearly-1630oo-people-sought-asylum-in-Sweden-in-20I5. html 
NEMO: Network of European Museum Organisations. (2015). Museums, migration and cultural diversity: Recommendations for museum work. Berlin: Deutscher Museumbund e. V.

Nikolić, D. (2015). Samla inte politiska poäng i mitt namn: Nationellt invandrarmuseum i Västra hamnen kritiseras [Do not raise political points in my name: Critique towards a national museum of immigrants in Västra hamnen]. Sydsvenskan. Retreived from https://www.sydsvenskan. se/2015-02-I9/samla-inte-politiska-poang-i-mitt-namn

Roque Rodríguez, A. (20I7). Museums Are Not Neutral [Blog post]. Retrieved from: https://www.anabelroro.com/blog/museums-are-not-neutral

Sadighiyan, S. (2017). Pour un musée connecté à tous ses citoyens : vers une définition radicale et transgenre. In F. Mairesse (Ed.), Définir le musée du XXIe siécle. Matériaux pour une discussion (pp. 28I-284). Paris: ICOFOM.

Sandell, R. (Ed.). (2002). Museums, Society, Inequality. London \& New York: Routledge.

Schubert, K. (2000). The Curator's Egg: The evolution of the museum concept from the French Revolution to the present day. London: One-Off Press.

Schwend, J. (2012). The Museum - A Site of Memory in Consumer Cultures. In S. Coelsch-Foisner, \& D. Brown (Eds.), The Museal Turn (pp. 19-33). Heidelberg, Germany: Universitätsverlag Winter.

Simon N. (2010). Participatory museum. Santa Cruz: Museum 2.o.

Smeds, K. (20I7). Museologins roll i museet [Museology's role in the museum]. In Forskaressäer till förstudie om ett nationellt demokrati- och migrationsmuseum i Malmö (pp. 69-73). Malmö, Sweden: Kulturförvaltningen, Malmö stad.

Stam, D. (1993). The Informed Muse: The Implications of 'The New Museology' for Museum Practice. In G. Corsane (Ed.), Heritage, Museums and Galleries (pp. 54-70). London \& New York: Routledge.

Sutherland, C. (20I4). Leaving and Longing: Migration Museums as Nation-Building Sites. Museum \& Society, I2 (I), II8-I3I.

Sverigedemokraterna. (20I7). Reservation: Förstudie om inrättande av ett demokrati-och migrationsmuseum i Malmö [Subject: Pilot study on establishing a museum for democracy and migration in Malmö]. Retrieved from https://malmo.sd.se/wp-content/uploads/sites/20/20I7/o4/ Kommunstyrelsen-2017-03-29-Reservation-Förstudie-om-inrättande-av-ett-demokrati-och-migrationsmuseum-i-Malmö.doc

The Russian Government. (20I0). Federal'nyj zakon ot 30 nojabrja 20Io g. N 327-FZ "O peredache religioznym organizacijam imushhestva religioznogo naznachenija, nahodjashhegosja v gosudarstvennoj ili municipal'noj sobstvennosti" [Federal Law from the zoth of November, 20I0 No 327 
"On the restitution of the property of religious nature to religious organisations from the State and municipalities]. Rossijskaja gazeta. Retrieved from https://rg.ru/20Io/12/o3/tserkovnoedobro-dok.html

Vergo, P. (1989). The New Museology. London: Reaktion Books.

Zabalueva, O. (20I7). Cultural Policies in Russian Museums. Museum International, 69(3-4), 38-49. 